\title{
Flóra OROSZ* \\ The protection of human rights in connection with working possibilities of special group of employees
}

\begin{abstract}
The author intends to analyse the special protection of disadvantage people - in particular to disabled people and people with changed working ability. These people are often cut off from the labour market, therefore, they can not participate there and even in the society. However, human rights, regulated in the Fundamental Law of Hungary, provide the opportunity for these people as well to work. Thus, these rights are essential for these people in order to ensure their employment. Labour law and social law protection confirms this constitutional protection. The study examines these three areas of protection.
\end{abstract}

Keywords: employment, human rights, protection, disabled people, people with changed working ability

\section{Introduction}

The concept of disadvantage situation is quite diverse. It can be interpreted in relation with individual persons, groups of people or territories, or in relation with children and adults (e.g. disabled people, low level of education, isolated and peripheral regions, regions of emigration, people with criminal record, etc.). There is no official concept of disadvantage situation but it means individuals and territories whose and which economic and social situation is less favourable than the average, that require active role from the state. However, if we consider the concept in connection with individuals, exactly in connection with children and adults (employees), the concept of disadvantage children is determined in Section 67/A of Child Protection Act ${ }^{1}$ and the concept of disadvantage employee in determined in Section 57/B (4) point 1-2 of the Act on Employment ${ }^{2}$. In Hungary disadvantage situation is treated by three policies: by labour market, regional development and educational policy. This study focuses on people from a less privileged labour market background, exactly on disabled people and people with changed working ability. I examine those human rights that protect these people, ensure them equal opportunity and provide them the possibility to work.

Flóra Orosz: The protection of human rights in connection with working possibilities of special group of employees. Journal of Agricultural and Environmental Law ISSN 1788-6171, 2020 Vol. XV No. 29 pp. 184-198, https://doi.org/10.21029/JAEL.2020.29.184

* dr. jur., PhD student, Ferenc Deák Doctoral School of Law and State Sciences, University of Miskolc, Faculty of Law, Department of Agricultural and Labour Law, e-mail: oroszflora93@gmail.com.

${ }^{1}$ Act XXXI of 1997 on the care of children and the management of guardianship.

2 Act IV of 1991 on the promotion of employment and the protection of unemployed (hereinafter referred to as: Act on employment). 
Flóra Orosz

The protection of human rights in connection with working possibilities of special group of employees
Journal of Agricultural and

Environmental Law

$29 / 2020$

The issue of examining the protection of human rights - in connection with labour market policy - of the above mentioned disadvantaged people is based on the topic of my $\mathrm{PhD}$ dissertation; within it I examine the operation of social farms. Disadvantaged people create the target group of social farms who have great unmet needs and they need care, support and who cannot make their life, employment situation better without help. Social farm is an innovative agricultural activity form which has important social and economic importance. Its social importance is based on that it improves the mental circumstances and employment possibilities of disadvantaged people. The aim of the farm is the social integration of these people and to help them get into/back to the labour market. Its economic importance is based on that the target group do agricultural activities on the farm which provides the employment of these people. Its economic importance is based on that the members of the target group do agricultural activities on the farm which realises their employment at the same time. The farm is the place where disadvantaged people can be actively involved. The target group of social farms is understood in a broad sense. ${ }^{3}$ The farm provides opportunities for disadvantaged people who are unable to make their situation better without help. The target group consists of mainly people with some kind of disability or long-term illness and people with changed working ability, but addicts, the homeless, the long-term unemployed, prisoners, former prisoners, participants in criminal rehabilitation programs, Roma, refugees also appear in the target group. ${ }^{4}$

The study concentrates especially on disabled people and people with changed working ability and it examines the protection of their human rights. Since these people are in a less favourable situation than others, special treatment and law enforcement is required which is even more important in relation with their employment possibilities. Therefore, the prevail and enforcement of human rights, that ensure them to be a real part of the society and labour market, is really important - compared to other members of the society it may be more important. According to my hypotheses, human rights examined in the study and their protection prove that these people need for these rights at all to be part of the society and the labour market, and prove the importance of equality and employment of disabled people and people with changed working ability, furthermore. The protection of human rights in connection with disabled people is complex; it raises constitutional, labour and social law protection. The study analyses all three areas but the main focus is on the constitutional law protection as it is the source of the lower level of acts.

\section{Conceptual basis}

Before analysing the protection of disabled people and people with changed working ability, it is important to determine the concept of them. These definitions play a significant role mainly in relation to the issues of their employment.

\footnotetext{
${ }^{3}$ Disadvantage people create the primary target group of social farms. However, social farms have a secondary target group to which pupils of difference educational institutions belong. For them social farm is the place of awareness-raising and enables them acquiring practical knowledge. The examination of this secondary group is beyond the scope.

${ }^{4}$ Dr. Gazsi, Jakubinyi \& Matthew 2015, 37-45.
} 
Flóra Orosz

The protection of human rights in connection with working possibilities of special group of employees
Journal of Agricultural and

Environmental Law

$29 / 2020$

These two concepts are often used as synonyms both in practice and theory, however, their meaning is different. The national terminology distinguishes between the concept of disabled people and people with changed working ability contrary to other Member States of the European Union where the concept of disabled people is used for both expressions. The connection between the two concepts is special. The group of disabled people creates a bigger category (set) and the group of people with changed working ability belongs to this bigger category as a smaller one (subset). ${ }^{5}$ Disabled people are 'outsiders' within the society and the labour market because of their disability. People with changed working ability have problem in work and have difficulties in the labour market because of their impairments. ${ }^{6}$

International law, the law of Member States and the Hungarian law determines the concept of disabled people differently. Article 1 of the Unites Nations' Convention on the Rights of Persons with Disabilities determines the concept of disabled people as follows: "Persons with disabilities include those who have long-term physical, mental, intellectual or sensory impairments which in interaction with various barriers may hinder their full and effective participation in society on an equal basis with others". This definition covers all kind of health damages as an umbrella term. In connection with the terminology of the Member States Nóra Jakab and Edit Kajtár established in the so called 'Empower Project' that the law of the surrounding Eastern and Western European countries use the concept of persons with disabilities. ${ }^{7}$ Contrary to the law of the Member States the Hungarian law distinguishes between the concept of (a) disabled people and (b) people with changed working ability. The Act XXVI of $1998^{8}$ determines the concept of disabled people, who are "persons with-long-term or permanent sensory, mental, physical, communicational impairments which confine or hinder their equal participation in society."'

The Act on employment determines the concept of people with changed working ability which says that "on the basis of the current classification of the rehabilitation authority or its predecessor people (a) whose health status is reduced to $60 \%$ or lower by the complex classification of the rehabilitation authority, (b) whose health status reduced by $40 \%$ on the basis of expert's report, opinion of a competent medical authority or official certificate, (c) whose work ability reduced by $50-100 \%$; or who is exempted from the complex qualification on the basis of a provision of law during the period of payment of invalidity benefits". ${ }^{10}$

It can be stated in relation with the two definitions that the chance of people with changed working ability is lower on the labour market, who relates to a category of insurance, meanwhile, most disabled people are not part of the labour market and thus, they do not have any insurance. ${ }^{11}$

\footnotetext{
${ }^{5}$ Jakab 2017, 205-209.

${ }^{6}$ Prugberger \& Jakab 2016, 172-173.

7 Jakab \& Kajtár 2013, 1-10.

8 Act XXVI of 1998 on the rights of disabled people and ensuring their equal opportunity (hereinafter referred to as: Act on disabled people).

${ }^{9}$ Section 4 point a) of the Act on disabled people.

${ }^{10}$ Section 58 (5) point $\mathrm{m}$ ).

11 Jakab 2015, 33-35.
} 
Flóra Orosz

The protection of human rights in connection with working possibilities of special group of employees
Journal of Agricultural and

Environmental Law

$29 / 2020$

\section{Constitutional protection}

After determining the definition of the target group (disabled people and people with changed working ability) in this chapter I examine the constitutional protection of these people. It is appropriate to begin the examination of human rights protection with the highest source of law, the Fundamental Law of Hungary, as it creates the basis of labour and social law protective measures, so the constitution determines the frame of protection. ${ }^{12}$ More articles of the Fundamental Law contain relevant human rights to which disabled people and people with changed working ability are (also) entitled. These rights are the right to equal treatment (prohibition of discrimination) which is a first-generation human right and the right to social security and work which are secondgeneration human rights.

First-generation human rights - so called classical human rights - deal essentially with liberty and participation in political life; they are fundamentally civil and political in nature. They serve negatively to protect the individual from excesses of the state. Firstgeneration rights include, among others, the right to equal treatment that ensures the equality of citizens. This right enjoys constitutional protection (as all first-generation human rights). ${ }^{13}$

Second-generation human rights are fundamentally economic, social, and cultural in nature which were recognized in the second half of the XIX century and got fundamental protection in the XX century. They guarantee different members of the citizenry equal conditions and treatment in connection with economic, social, and cultural area - so these rights ensure to get a job, to get support in case of unemployment, to bargain collectively, express oneself free in scientific and art life, etc. These rights differ from first-generation human rights in that they depend on the economic performance of the state. If the state is doing economically well, it can guarantee social rights more widely. ${ }^{14}$ Other difference is that they impose upon the government the duty to respect and promote and fulfil them, so the duty of the government is the realization of these positive rights. Beside the legal guarantee of the constitution and the lower level of legal sources, an adequate financial guarantee institutional network for providing social rights, the conditions of entitlement of social institutions and financial support - is also required for these rights. ${ }^{15}$ In connection with the duty of the state the Constitutional Court stated in its Decision no. 25/2016 (XII. 21.) that "...the obligation of the state is, on one hand, to establish an institutional network through which human rights can prevail, on the other hand, to determine the conditions of entitlements of social institutions". The regulation of social rights in the Fundamental Law serves not only as protective measures of human rights - first of all in relation with the target group is this study - but the legislation and the users of the law shall consider them. Thus, neither the legislator may legislate contrary to the rights guaranteed by the constitution, nor the users of the law may break to law.

\footnotetext{
12 Zaccari 2015, 40-48.

${ }^{13}$ Sári \& Somody 2008.

${ }^{14}$ Balogh 2011b, 307-308.

15 Téglási 2011, 3-4.; Kiss 2016, 358.
} 
Flóra Orosz

The protection of human rights in connection with working possibilities of special group of employees
Journal of Agricultural and

Environmental Law

$29 / 2020$

This is completed and confirmed by the Constitutional Court that may interpret and determine the exact content of the rights. ${ }^{16}$ Although, the second-generation human rights provide important human rights for the citizens which are confirmed by international and EU documents - the examination of these document is beyond the scope -, they are not considered as strong individual rights as first-generation rights. Consequently this means that the constitutional protection of second-generation human rights is also lower. ${ }^{17}$ When we analyse the constitutional protection of social rights, it shall be mentioned that social rights can be categorized into three groups according to their constitutional protection. This categorization is relevant for the above mentioned two social rights as well as they belong to different groups and have different characteristics. There three groups are a) fundamental rights, b) constitutional rights other than fundamental rights and c) state objectives. ${ }^{18}$ The characteristics of the categories are determined in more detailed later at each right.

Apart from the lower constitutional protection, the right to social security and work equally plays a significant role for disabled people and people with changed working ability as the right to equal treatment. The reason of it is that these people need more support, care and help than people without disabilities. Positive discrimination shall be applied in these people's case because of their limited equality and work ability. According to these facts, the examination of the above mentioned three human rights is essential.

\subsection{The right to equal treatment}

Article XV of Fundamental Law provides the principle of equality and nondiscrimination that plays an important role in terms of rights and protected interests of employees as discrimination occurs in labour law quite often. Fundamental Law similarly to the Constitution ${ }^{19}$ approaches equality from two directions: a) on one hand, it states that everyone is equal before the law, ${ }^{20} \mathrm{~b}$ ) on the other hand, it prohibits discrimination, ${ }^{21}$ so it guarantees human rights to everyone without any discrimination. ${ }^{22}$ It is necessary to highlight that equality in social life shall be distinguish from the principle of equality in the legal sense. While the previous sense can not be interpreted from a constitutional point of view, in the latter sense equality is protected by constitutional law. ${ }^{23}$ According to the aim of the study, the latter sense has

\footnotetext{
16 Zaccaria $2015,48-50$.

${ }^{17}$ In connection with the protection of constitutional rights, two models can be distinguished: (a) social rights should not be regulated within the constitution, or if they are regulated they do not provide individual rights; (b) classical human rights and social rights are interdependent, they are indivisible. See more details Balogh 2011b, 305-306.; Balogh 2006, 25-37.

${ }_{18}$ Balogh 2011b, 308.

19 The previous constitution of Hungary was called Constitution. Since the adoption of the constitution in 2011, it is called Fundamental Law.

20 Although, the Constitution did not contain the provision of 'everybody is equal,' Article XV

(1) of Fundamental Law contains that.

${ }^{21}$ Constitutional Court Decision no. 45/2000. (XII.8.).

${ }^{22}$ Constitutional Court Decision no. 9/2016. (IV.6.).

${ }^{23}$ Kiss 2003, 5-6.
} 
significance. The infringement of the principle of equality (in the legal sense) may be interpreted in relation to a right or obligation: "discrimination means the deprivation of a right or the imposition of an obligation." 24 Article XV (2) lists, in illustrative list, the cases when distinction constitutes to discrimination. In connection with the illustrative list, point [27] of the Constitutional Court Decision no. 3206/2014. (VII.21.) states that “...listed characteristics - race, colour, gender, disability, national or social origin, etc. are immutable characteristics of a person that can not be influenced, that is why the prohibition of discrimination serves the protection of these people." Disability is listed within the illustrative list as a personal quality that is considered to be a protected characteristic in the frame of the principle of equality. Disabled people shall live together with their disability, they are not able to change that, however, they are also entitled to human rights. Furthermore, Article XV (4)-(5) highlights disabled people as a group requiring special care and protection in order to whose equality and social inclusion Hungary shall help by means of separate measures. Such measure was e.g. the establishment of Secretary of State for Social Inclusion within the Ministry of Human Resources and a separate institution, the Equal Treatment Authority ${ }^{25}$ for providing effective legal protection against discrimination. ${ }^{26}$

It shall note that discrimination may be not only prejudicial that is prohibited by the Fundamental Law but may be positive as well. Exceptionally, it is possible to derogate from the general prohibition but only if that constitutes positive discrimination for achieving equality. Therefore, not every distinction is prohibited but only discrimination without reason and which violates human dignity. ${ }^{27}$ This state was confirmed by the Constitutional Court Decision no. 9/1990. (IV.25.) that determines that "... the prohibition of discrimination does not mean that every discrimination is prohibited. The prohibition of discrimination means that the law shall treat everybody equally (as persons of equal dignity), thus the criteria for entitlements and benefits should be determined with equal regard to individual needs... But if a social aim or constitutional right can be enforced by equality in the narrow sense, then such positive discrimination can not be declared unconstitutional."

\subsection{Right to social security}

Article XIX of Fundamental Law regulates the right to social security. Social security means that life situation when subsistence is ensured and the quality of life presumes welfare. According to Albert Takács “... social security is a quality of life that relates to welfare." 28 Social security shall be applied when the work, the income deriving from that and the work ability itself is temporarily or consistently being

\footnotetext{
${ }^{24}$ Constitutional Court Decision no. 45/2000. (XII.8.), point [3.2.].

25 The authority was established according to the Act CXXV of 2003 on equal treatment and the promotion of equal opportunity which task is to very whether the requirement of equal treatment prevails.

26 Explanatory memorandum to Article XV of the Fundamental Law; commentary on this article of Complex Law Library; opinion of the case law analysis group of the Supreme Court.

${ }^{27}$ Balogh 2011a, 137-140.

28 Takács 2011, 79.
} 
Flóra Orosz

The protection of human rights in connection with working possibilities of special group of employees
Journal of Agricultural and

Environmental Law

$29 / 2020$

restricted, suspended or permanently being terminated due to unforeseen circumstance or risk. József Hajdú says that right to social security is subsidiary to the right to work, ${ }^{29}$ so the right to social security becomes relevant when the right to work terminates.

The right to social security belongs to the second group regarding the intensity of constitutional protection, so it is a constitutional right other than fundamental rights. The characteristic of this category is that these rights are not individual rights, they can not be enforced on the basis of the constitution but they shall be ensured by further regulation. ${ }^{30}$

It shall note that Article XIX resulted change and a new approach compared to Section 70/E of the (previous) Constitution. ${ }^{31}$ Article XIX (1) determines the intention of Hungary to provide social security for every Hungarian citizen. This regulation brought one of the most significant changes by making clear that the Fundamental Law regulates the right to social security not as a right - social security as a human right was disputed previously and the Constitutional Court did not considered it as a real human right that was expressed is several Constitutional Court Decision - but 'only' as a state objective ${ }^{32}$. Instead the regulation of Section $70 / \mathrm{E}$ of the Constitution "Citizen of the Hungarian Republic have right to social security...", the Fundamental Law states that the state shall only strive to provide social security to its citizen. ${ }^{33}$ According to others, this change is a withdrawal compared to the regulation of the previous Constitution which derogates the importance of this right. However, taking into account that the Constitutional Court did not consider the right to social security as real human right in its previous interpretation, therefore, this change can not consider as a withdrawal. This right was considered as a state objective so far and it is regulated as such in the Fundamental Law, ${ }^{34}$ thus it is considered that the previous interpretation of the Constitutional Court was codified. Furthermore, the fact that the Fundamental Law still regulates social security proves the importance of this right. However, there is no doubt that the regulation as a state objective provides more possibilities - within constitutional framework - for the state to establish and operate the social security system. Invalidity, disability and involuntary unemployment are listed in the exhaustive list ${ }^{35}$ according to which individuals are entitled to statutory support. The legislator is free to decide the form and the details of the subsidy. According to Article XIX (2) the state establishes social security in Hungary by the system of social institutions and measures. The Fundamental Law brought change in the instruments of social security.

\footnotetext{
${ }^{29}$ Hajdú 2015, 34.

${ }^{30}$ Balogh 2011b, 309.

31 The Constitutional Court Decision no. 23/2013. (IX. 25.), ABH 2013, 692 treated firstly with the new regulation. See the regulatory changes Rácz 2016, 535-542.; Téglási 2011.

32 The Constitutional Court in its following Decisions, formulated after adopting the Fundamental Law, treated with the classification of the right to social security as a state goal: 40/2012. (XII. 6.), 3217/2014. (IX.22.), 28/2015. (IX. 24.), 9/2016. (IV.6.).

33 See more details Juhász 2012, 44-48.; Téglási 2019.

${ }^{34}$ Jakab A 2011, 215.

35 Compared to the Constitution, the subject scope of the right to social security in the Fundamental Law has also changed. While the Constitution has listed the range of beneficiaries in an exemplary manner, the Fundamental Law guarantees the right to social security only for the subjects included in the exhaustive list.
} 
Flóra Orosz

The protection of human rights in connection with working possibilities of special group of employees
Journal of Agricultural and

Environmental Law

$29 / 2020$

While the Constitution determined social insurance and the system of social institutions within the instruments of social security, the instruments of Fundamental Law no longer include social insurance but social institutions remained among them and social instruments was expanded with social measures. The abandonment of the instrument of social insurance raises the problem that Hungary breaches the obligations deriving from international documents - Article 9 of International Covenant on Economic, Social and Cultural Rights and ILO Convention no. 102 - and the Article 12 of European Social Charta. ${ }^{36}$

With respect to the statement of András Téglási and István Hoffman, Article XIX did not result a significantly different conception in relation to the constitutional protection of social security comparing the practice of the Constitutional Court before and after Fundamental Law came into force.

Based on the above mentioned facts, the right to social security constitutes to be essential - despite the new approach and change of Fundamental Law - as it important both for disabled people and people with changed working ability to maintain and provide their subsistence and the subsidies to facilitate it.

\subsection{Right to work}

Finally, Article XII of Fundamental Law regulates the right to work. This social right belongs to the first category of social rights so it constitutes to be a fundamental right. Fundamental rights are originated from a first-generation human right. In this case the right to work is originated from the individual action autonomy. The protection of these social rights is equivalent with the protection of first-generation human rights that can only be restricted on the basis of necessity and proportionality test. ${ }^{37}$ On this basis the right to work constitutes to be a stronger human right than the right $t$ social security but in my opinion both rights are of particular importance for the target group.

Article XII (1) provides right and prescribes 'obligation' for citizen as well in a complex way. Accordingly, everyone has right to pursue a freely chosen work and occupation (and to conduct a business) but everyone is obliged to work according to his/her abilities and possibilities - with regulation is new in the Fundamental Law. The regulation of this right in the Fundamental Law also brought changes, similarly to the right of social security, in accordance with the practice of the Constitutional Court. Previously, Section 70/B of the Constitution regulated in one sentence both the positive (right to engage in work as a social right) and negative (right to pursue a freely chosen occupation) aspects of the right to work, of which Constitutional Court recognised only the negative aspect as an individual right and granted for that constitutional protection. ${ }^{38}$ The re-regulation of the right to work confirmed the practice of the Constitutional Court and Fundamental Law regulates in Article XII only the negative aspect of this right as an individual right.

\footnotetext{
36 Rácz 2016, 538-539.

37 Balogh 2011b, 308.

${ }^{38}$ Constitutional Court Decision no. 21/1994. (IV.16.) and the commentary of Wolters Kluwer Law Library in connection with Article XII.
} 
However, the legislator defines work not only as a right but also as an expectation for providing the operation of the state. ${ }^{39}$ Article XII (2) determines the positive aspect of the right as a state objective according to which the state shall strive to create the conditions of work - appropriate employment policy, job creation. ${ }^{40}$

With regard to the subject of the right to work, it is worth nothing that a distinction shall be made between the employment of disabled people and the employment of incapacitated people. We would think that a disabled person is incapable in the same time, which is true in many cases but not necessarily in all cases. So somebody will not be automatically incapable because he/she has some kind of disability. The Constitutional Court examined in its Decision no. 39/2011. (V.31.) that how guarantees of the right to work prevail in relation to incapacitated adult because of disability. While the Constitution provided only the right to pursue a freely chosen occupation, the Fundamental Law determines the obligation to work according to one's abilities and possibilities. Therefore, if a disabled person or incapacitated adult because of disability is able or would like to work, he/she has the right to do so - and he/she is even obliges to work according to the Fundamental law -, so it is appropriate to permit. The Constitutional Court in its Decision no. 39/2011. (V.31.), point [1.1] determined that "... complete exclusion of incapacitated people from employment may raise constitutional concerns." Consequently, my statement according to which the opportunity to work shall be provided for incapacitated people who are able and willing to work, is justified. Furthermore, the Constitutional Court also determined that legislation shall seek to increase the employment opportunities of incapacitated people. Hungary seeks to fulfil this provision by regulation of Article XII (2) of the Fundamental Law "...all people who have the ability to work and want to work to get work."

In the following, I examine the legislation ensuring the enforcement and further protection of these three human rights that creates the labour and social law dimension of the protection.

\section{Labour and social law protection}

\subsection{Protection provided by the Act on equal treatment and the promotion of equal opportunities}

Beside the provisions of the Fundamental Law, the Act on Equal Treatment ${ }^{41}$ and the promotion of Equal Opportunities (hereinafter referred to as: Act on Equal Treatment) contains the most important sectoral level of protection in relation to disabled people and people with changed working ability. The aim of protection is determined already in the beginning of the Act on Equal Treatment, within the legislative purposes according to which "The Parliament, acknowledging every person's right to live as a person of equal dignity, intending to provide effective legal aid to those suffering from negative discrimination, declaring that the promotion of equal

\footnotetext{
39 According to the explanatory memorandum to the Act of Article XII.

40 Juhász 2012, 35-37.; Balogh 2011b, 313-315.

${ }^{41}$ Act CXXV of 2003 on equal treatment and the promotion of equal opportunities.
} 
Flóra Orosz

The protection of human rights in connection with working possibilities of special group of employees
Journal of Agricultural and

Environmental Law

$29 / 2020$

opportunities is principally the duty of the State, having regard to Articles II and XV of the Fundamental Law, the international obligations of the Republic and the legal acts of the European Union" enacts the Act.

The Act on Equal Treatment defines the cases that constitute the violation of equal treatment, thereby causing direct and indirect discrimination. ${ }^{42}$ In relation to these cases, the Act declares the instruments that the person who has suffered discrimination may use, so it determines the legal consequences of violating the provisions of the Act. ${ }^{43}$ Among infringements the Act separately defines the infringements in the field of employment ${ }^{44}$ and social security. ${ }^{45}$ In the field of employment, the employer infringes the requirement of equal treatment, in particular, if he/she does so in connection with access to employment, the establishment or the existence of an employment relationship, or in connection with working conditions. In the field of social security, infringement against the target group may take place with regard to claiming or providing social benefits. With regard to the examined group of persons, the violation of the requirement of equal treatment occurs most frequently in these cases.

\subsection{Protective provisions of the Labour Code concerning the target group}

After the Act on Equal Treatment, I examine those provisions of the Labour Code $^{46}$ that provide the target group some kind of guarantee and protection ${ }^{47}$ in connection with the employment of them. However, the Labour Code contains only a certain number of relevant provisions contrary to the Act on Equal Treatment.

Section 51 (5) of the Labour Code states that "In the employment of persons with disabilities appropriate steps shall be taken to ensure that reasonable accommodation is provided." However, the Labour Code does not define exactly what it means under 'reasonable accommodation,' thus its meaning hall be developed in the judicial practice.

Section 53 (3) point d) states that "An employee may not be transferred to work at another location without the employee's consent if having suffered a degree of health impairment of at least fifty per cent as diagnosed by the body of rehabilitation experts." According to this provision, employment of a person with changed working ability other than determined in the employment contract is limited, it can be applied without the consent of the employee.

Section 66 (7) contains the next relevant provision that ensures protection against dismissal for people with changed working ability. It states that "The employer may terminate by notice the employment relationship of a worker who is receiving rehabilitation treatment or rehabilitation benefits due to the worker's capacity related to medical reasons if the worker can no longer be employed in his/her original position and no other job is available that is considered appropriate for his/her medical

42 Section 8-9 of Act on Equal Treatment.

${ }^{43}$ Section 12-17/D of Act on Equal Treatment.

${ }^{44}$ Section 21-23 of Act on Equal Treatment.

45 Section 24 of Act on Equal Treatment.

46 Act I of 2012 on the Labour Code.

${ }^{47}$ See more about the regulation of the tare group within the Labour Code Jakab 2015, 205-209. 
Flóra Orosz

The protection of human rights in connection with working possibilities of special group of employees
Journal of Agricultural and

Environmental Law

$29 / 2020$

condition, or if the employee refuses to accept a job offered by the employer without good reason." The protection against dismissal considered to be dismissal limitation that provides protection only against dismissal on the grounds of health problem. This limitation means at the same time important protection, as someone is still able to work after the impairment, the employer must provide for him/her the opportunity to work.

Finally, Section 212 has relevance in relation with disabled people when disability also affects their capacity. Section 212 states that: “(1) Incapacitated workers may conclude employment relationships only for jobs which they are capable to handle on a stable and continuous basis in the light of their medical condition. (2) The functions of the employee's job shall be determined by definition of the related responsibilities in detail. The employee's medical examination shall cover the employee's ability to handle the functions of the job. (3) The employee's work shall be supervised continuously so as to ensure that the requirements of occupational safety and health are satisfied. (4) The provisions of Chapter XIV shall not apply to such employees; furthermore, the provisions pertaining to young workers shall apply." With this provision the legislator creates the opportunity of employment for mentally impaired people. In order to guarantee employment of these workers under the appropriate conditions, the legislator provides that the tasks to be carried out by the worker must be defined in detail and the appropriate working conditions and their monitoring should be ensured.

Although the Labour Code contains less provision in relation with the target group but these provisions are also important. However, I agree with Nóra Jakab who says that the non-coherent definition of these two categories of people, which, in some cases, seems to be justified, however, e.g. the requirement of reasonable accommodation should be apply to both subjects.

Over the Act on Equal Treatment and the Labour Code there are more acts that were adopted to ensure human rights deriving for the Fundamental Law.

The Act on Social Administration and Social Benefits ${ }^{48}$ determines the forms and organization of certain social benefits provided by the state in order to create and maintain social security, the conditions of entitlement to social benefits and the guarantees of their enforcement.

The Act on the Rights and Equal Opportunities of Disabled People ${ }^{49}$ serves in the interest of disabled people the alleviation of their disadvantages, the establishment of equal opportunity and forming the attitude of the society. The aim of the act is to determine the rights of disabled people and instruments of enforcing rights, furthermore, the regulation of complex rehabilitation of these people and as a result ensuring equal opportunity, independent lifestyle and active participation in social life.

\footnotetext{
48 Act III of 1992 on social administration and social benefits.

49 Act XXVI of 1998 on the rights and equal opportunities of disabled people.
} 
Flóra Orosz

The protection of human rights in connection with working possibilities of special group of employees
Journal of Agricultural and

Environmental Law

$29 / 2020$

Finally, the Act on the Care of Persons with Disabilities ${ }^{50}$ regulates protective provisions in connection with people with changed working ability. The purpose of this act is to promote the reintegration, employment and employment-centered rehabilitation of these people on the basis of their remaining and improvable capacities and to replace earning due to the lost of income.

\section{The role of social farm}

Following the above-mentioned legal protection, a brief introduction shall be made of the special protection - social farm services - afforded by social farms to the subject of the study, which was the basis for the study.

The concept of social farm can be defined as a multifunctional agricultural activity form that performs important social and ecological function as well in addition to traditional agricultural activities (economic function). ${ }^{51} \mathrm{It}$ is necessary to emphasize that it is not a separate organizational form but an activity form that may be operated basically in any organizational form. ${ }^{52}$ Multifunctional farms differ from traditional farms in several aspects. They broaden, deepen and lay their activities and relationships on a new basis. The social role of agriculture extends for many other functions in addition to agricultural activities. For example, it provides employment, integrates disadvantage (from social land employment aspects) people, maintains traditions, care for rural landscape, etc. ${ }^{53}$ This means the system and essence of social farm service. The model of social farm is based on two pillars: on agricultural activities and on care and support. The farm itself is the basis of the model that provides skills development, rehabilitation and integration for the users of the social farm service by agricultural activities. By all this the aim of the farm is to employ the target group, to provide them job opportunities and, through this, to enable these people to become active, fullfledged members of the society and the labour market.

In connection with the target group of the social farm it can be stated specially about disabled people and people with changed working ability and about disabled situation in general, that these people are different, their situation results in different condition, circumstance. However, it does not mean that the life of these people is worth less than other's life but they are different. Therefore, they need help, even if not in all areas of life but in many aspects. Deriving from the right to social security, the state is responsible for establishing the system of social institutional and to operate that. Furthermore, it is also the task of the state in connection with the right to work to provide working conditions for all people who are able and willing to work. However, there are areas where social care is inadequate or is missing or the possibility of work is limited. Such area is the integration (both from social land employment aspect) of disabled people and people with changed working ability. It causes problem and difficulties for them to find a job and in many cases they do not get opportunity for it

\footnotetext{
${ }^{50}$ Act CXCI of 2011 on the care of people with changed working ability and on Amendment to Certain Laws.

51 Orosz 2018, 221.

52 See more about the possible operational form of social farms Orosz 2019, 416-432.

${ }^{53}$ Csák 2015, 1-10.; Csák \& Kenderes 2016, 145-152.; Csák \& Kenderes 2016, 1-11.
} 
Flóra Orosz

The protection of human rights in connection with working possibilities of special group of employees
Journal of Agricultural and

Environmental Law

$29 / 2020$

at all. Social farm is intend to fill this gap and help these people (as well) by providing them appropriate mental development and work opportunities. As it was mentioned before, social farm activity is based on two pillars: on agricultural activities and on care and support. The central element of the farm activity is the farm itself that ensure the two pillars, so the development of skills, rehabilitation and integration. ${ }^{54}$ Integration is equivalent to the support service of the farm that creates the essence of the farm. So the primary aim of the farm is the integration of the target group and the secondary aim is employment, providing work opportunity. The farm tries to achieve these aims by agricultural activities.

Overall, people (target group) may feel themselves as useful members and they may become useful members of the society thanks to social farm service that provides significant developments. ${ }^{55}$ So the farm ensures the target group the right to social security and work.

\section{Closing thoughts}

Disadvantages people, including disabled people and people with changed working ability are also the members of our society, even if they are different from other people. These people are also entitled to constitutional human rights, from which certain rights play significant role in their case, namely the right to equal treatment, the right to social security and work. These rights guarantee them that they also entitled to well-being and adequate living conditions, as well as the right to pursue a freely chosen work without discrimination. In their cases, positive discrimination can be applied if that is justified and their rights can be enforced in this way.

Social farm is a model that seeks to fill the gap that affects disadvantaged people. Thus, the farm intends to solve their problems, so discrimination, social exclusion, from labour market, significant restriction of employment opportunities by integrating them, providing them supportive farm service through agricultural activities.

${ }^{54}$ Leck, Evans \& Upton 2014, 313-314.; Lanfranchi, Giannetto \& Abbate \& Dimitrova 2015, 711.

55 Orosz 2018, 222-223. 
Flóra Orosz

The protection of human rights in connection with working possibilities of special group of employees
Journal of Agricultural and

Environmental Law

$29 / 2020$

\section{Bibliography}

1. Balogh Zs (2006) Az értelmezés hatalma - szociális jogok az Alkotmányban, in: Hajas Barnabás \& Schanda Balázs (eds.) Formtori Iuris Publici. Ünnepi Kötet Kilényi Géza professzor hetvenedik születésnapjára, Szent István Társulat, Budapest, pp.25-37.

2. Balogh Zs (2011a) A diszkrimináció tilalma, in: Schanda B \& Balogh Zs (ed.) Alkotmányjog - Alapjogok, PPKE JÁK, Budapest, pp. 123-140.

3. Balogh Zs (2011b) Szociális jogok, in: Schanda B \& Balogh Zs (eds.) AlkotmányAlapjogok, PPKE JÁK, Budapest, pp. 301-326.

4. Csák Cs (2015) Szociális inklúzió megvalósulása a szociális farmrendszer keretei között, in: Veresné Somosi M \& Lipták K (eds.) „Mérleg és Kibivások” IX. Nemzetközi Tudományos Konferencia. A Gazdaságtudományi Kar megalapitásának 25. évfordulója alkalmából, Konferencia Kiadvány, Miskolc-Lillafüred, pp.1-10.

5. Csák Cs \& Kenderes Gy (2016a) Hátrányos helyzetű személyek foglalkoztatási lehetőségei és annak bizonytalanságai a mezőgazdaságban, in: Homoki-Nagy M \& Hajdú J (eds.) Ünnepi kötet Dr. Cqucz. Ottó egyetemi tanár 70. sqületésnapjára, Acta Universitas Szegediensis. Acta Juridica et Politica, pp. 141-152.

6. Csák Cs \& Kenderes Gy (2016b) New organizational and employment opportunities of the multifunctional agriculture, in: Kékesi T (ed.) The Publications of the MultiScience - XXX. microCAD International Multidisciplinary Scientific Conference, University of Miskolc, pp. 1-11.

7. Dr. Gazsi A, Jakubinyi L \& Matthew H (2015) Célcsoportok - a szociális farmszolgáltatások igénybevevői, in: Kajner P \& Jakubinyi L (eds.) Szociális farmok létrehozása Magyarországon, Szimbiózis Alapítvány, Miskolc, pp. 37-45.

8. Hajdú J (2015) A szociális biztonság jelentése és védelme az Alaptörvényben, in: Balogh E (ed.) A történeti alkotmánytól az. Alaptörvényig, Pólay Elemér Alapítvány Jurisperitus Betéti Társasága, Szeged.

9. Jakab A (2011) Az üj Alaptörvény keletkezése és gyakorlati következményei, HVGORAC, Budapest.

10. Jakab N (2015) A munkavállalói jogalanyiság munkajogi és szociális jogi kérdései, különös tekintettel a megváltozott munkaképességü és fogyatékos személyekre, Bíbor Kiadó, Miskolc.

11. Jakab N (2017) A fogyatékosság szociálpolitikai összefüggései, in: Mélypataki G (ed.) A szociálpolitika jogi alapjai a XXI. század társadalmi kibivásainak tükrében, Bíbor Kiadó, Miskolc, pp. 203-221.

12. Jakab N \& Kajtár E (2013) Empower Project Questionnaire Hungary. 1-10. A kérdőív a Visegrad Fund által támogatott Empower Project keretében készült, http://empower.hu/publications/category/4-filled-in-questioners

13. Jakab N, Mélypataki G \& Szekeres B (2017) A szociálpolitika jogi alapjai a XXI. század társadalmi kibivásainak tükrében, Bíbor Kiadó, Miskolc.

14. Juhász G (2012) A gazdasági és szociális jogok védelme az Alkotmányban és az Alaptörvényben, Fundementum, 16(1), pp. 35-49.

15. Kiss B (2016) A szociális biztonság alkotmányjogi megítélése Magyarországon a rendszerváltozást követően, Acta Universitatis Szegediensis: Acta juridica et politica, (1), pp. 357-362. 
Flóra Orosz

The protection of human rights in connection with working possibilities of special group of employees
Journal of Agricultural and

Environmental Law

$29 / 2020$

16. Kiss B (2003) Az egyenlő bánásmód elvének és a hátrányos megkülönböztetés tilalmának jogi szabályozása, Acta Universitas Szegediensis: Acta Juridica et Politica, (12), pp. 3-38.

17. Lanfranchi M, Giannetto C, Abbate T \& Dimitrova V (2015) Agriculture and the social farm: Expression of the multifunctional model of agriculture as a solution to the economic crisis in rural areas, Bulgarian Journal of Agricultural Science, 21(4), 711-718.

18. Leck C, Evans N \& Upton D (2014) Agriculture- who cares? An investigation of 'care farming' in the UK. Journal of Rural Studies. 34(Apr.), pp. 313-325. https://doi.org/10.1016/j.jrurstud.2014.01.012

19. Orosz F (2018) Társadalmi felelősségvállalás a mezőgazdaság keretei között különös tekintettel a nyugat-európai megoldásokra, in: Haffner T (ed.) IV. Fiatalok Európában Konferencia - Tanulmánykötet, Sopianae Kulturális Egyesület, Pécs, pp. 219-230.

20. Orosz F (2019) A mezőgazdasági tevékenység végzésének feltételei és korlátai szervezeti és pénzügyi keretek, Publicationes Universitatis Miskolcinensis Sectio Juridica et Politica, 37(2), pp. 416-432. Orosz F (2018) Társadalmi felelősségvállalás a mezőgazdaság keretei között - különös tekintettel a nyugat-európai megoldásokra, in: Haffner T (ed.) IV. Fiatalok Európában Konferencia Tanulmánykëtet, Sopianae Kulturális Egyesület, Pécs, pp. 219-230.

21. Prugberger T \& Jakab N (2016) A foglalkoztatás elósegités és igazgatás joga, Bíbor Kiadó, Miskolc.

22. Rácz Z (2016) A szociális biztonsághoz való jog Magyarországon a rendszerváltozás óta eltelt időszakban, SZTE, Szeged, pp.535-542.

23. Sári J \& Somody B (2008) Alapjogok, Alkotmányjog II, Osiris Kiadó, Budapest, Digitális

Tankönyvtár https://regi.tankonyvtar.hu/hu/tartalom/tamop425/2011_0001_520_alapjogok _alkotmanytan_ii/ch01s02.html [11.10.2020.]

24. Takács A (2011) Szociális jogok az Alkotmányban és a munka alkotmányjogi szerepe, in: Molnár B \& Gyombolai Zs \& Téglási A (eds.) Gazdasági alapjogok és az új magyar Alkotmány, Kiadta az Országgyúlés Emberi jogi, kisebbségi, civil- és vallásügyi bizottsága. Budapest, pp. 76-86.

25. Téglási A (2011) A szociális állam „erodálása” vagy megmentése? - avagy a szociális biztonság az új Alaptörvényben, Jogelméleti szemle, (4).

26. Téglási A (2019) A szociális biztonság alkotmányos védelme az Alaptörvény hatálybalépése előtt és után, Acta Humana, (2), 85-106. doi: 10.32566/ah.2019.2.5

27. Zaccaria M L (2015) Az egyenlö bánásmód elvének érvényesülése a munkajog területén a magyar joggyakorlatba, HVG-ORAC Lap- és Könyvkiadó, Budapest. 